\title{
PENGOLAHAN AIR LIMBAH INDUSTRI PENYAMAKAN KULIT MENGGUNAKAN ABU TERBANG BAGAS SECARA BATCH
}

\section{(TANNERY WASTEWATER TREATMENT USING BAGASSE FLY ASH: BATCH STUDY)}

\author{
Muhammad Sholeh $^{1)}$, Agus Prasetya ${ }^{2)}$, Sarto $^{2)}$ \\ Email: sholeh_tahunan@yahoo.com \\ Diterima: 1 Maret 2012 Disetujui: 29 Mei 2012
}

\begin{abstract}
The objective of this research was to evaluate the adsorption ability of chemically activated bagasse fly ash using $\mathrm{H}_{2} \mathrm{O}_{2}$ or $\mathrm{H}_{2} \mathrm{SO}_{4}$ to remove $\mathrm{COD}$ from tannery wastewater and to obtain adsorption isotherm model in batch system.

Two stages have been carried out, namely the activation experiment and the adsorption isotherm experiment. In the activation experiment, effect of $\mathrm{H}_{2} \mathrm{O}_{2}$ dan $\mathrm{H}_{2} \mathrm{SO}_{4}(3 \%$ and $7,5 \% \mathrm{w} / \mathrm{w})$ were studied. The best result of the variation was used in the next experiment. In the adsorption isotherm experiment, variation of the initial concentrations of COD from 52,53 to $1665,79 \mathrm{mg} / \mathrm{L}$ and mass of bagasse fly ash from 0,1 to 0,4 $\mathrm{g}$ were used. Equilibrium data was used to evaluate the parameters in the Langmuir, Freundlich, and Temkin equations. The best model was evaluated using determination coefficients.

The results showed that bagas fly ash had better ability to reduce the COD when it was not activated with $\mathrm{H}_{2} \mathrm{O}_{2}$ nor $\mathrm{H}_{2} \mathrm{SO}_{4}(3 \%$ and 7,5\%). Freundlich model was best to describe $\mathrm{COD}$ removal using bagasse fly ash in batch system. Freundlich equation constants $K_{F}$ and $n$ were $0,4360(\mathrm{mg} / \mathrm{g}) /(\mathrm{L} / \mathrm{mg})^{1 / n}$ and 1,2969 respectively and the determination coefficient obtained was 0,93 .
\end{abstract}

Keywords: Chemical Oxygen Demand, tannery wastewater, bagasse fly ash, adsorption

\section{ABSTRAK}

Penelitian ini bertujuan untuk menguji peningkatan kemampuan abu terbang bagas yang diaktivasi secara kimia menggunakan $\mathrm{H}_{2} \mathrm{O}_{2}$ atau $\mathrm{H}_{2} \mathrm{SO}_{4}$ dalam mengurangi COD air limbah industri penyamakan kulit dan mendapatkan model kesetimbangan adsorption isotherm yang sesuai secara batch.

Penelitian dilakukan melalui dua tahapan, yaitu percobaan aktivasi abu terbang bagas dan percobaan adsorption isotherm. Pada percobaan aktivasi abu terbang bagas dilakukan variasi kadar $\mathrm{H}_{2} \mathrm{O}_{2}$ dan $\mathrm{H}_{2} \mathrm{SO}_{4}$ $(3 \%$ dan $7,5 \% \mathrm{w} / \mathrm{w})$. Variasi yang memberikan hasil yang terbaik digunakan pada percobaan selanjutnya. Pada percobaan adsorption isotherm variasi yang dilakukan adalah konsentrasi COD limbah antara 52,53 sampai dengan $1665,79 \mathrm{mg} / \mathrm{L}$ dan massa abu terbang bagas antara 0,1 sampai dengan $0,4 \mathrm{~g}$. Data kesetimbangan yang diperoleh digunakan untuk mengevaluasi parameter-parameter dalam persamaan Langmuir, Freundlich, dan Temkin. Persamaan yang cocok ditentukan dari koefisien determinasi yang diperoleh.

Hasil penelitian menunjukkan bahwa abu terbang bagas memiliki kemampuan untuk mengurangi COD yang lebih baik bila tidak diaktivasi dengan $\mathrm{H}_{2} \mathrm{O}_{2}$ maupun $\mathrm{H}_{2} \mathrm{SO}_{4}(3 \%$ dan $7,5 \%)$. Model Freundlich paling cocok untuk menggambarkan proses pengurangan COD dengan abu terbang bagas secara batch. Konstanta persamaan Freundlich $K_{\mathrm{F}}$ dan $n$ yang diperoleh berturut-turut sebesar $\mathbf{0 , 4 3 6 0}(\mathbf{m g} / \mathbf{g}) /(\mathbf{L} / \mathbf{m g})^{1 / \mathbf{n}}$ dan $\mathbf{1 , 2 9 6 9}$ dengan nilai koefisien determinasi yang didapatkan yaitu 0,93 .

Kata kunci: Chemical Oxygen Demand, air limbah industri penyamakan kulit, abu terbang bagas, adsorpsi

${ }^{1)}$ Balai Besar Kulit, Karet dan Plastik, Yogyakarta ${ }^{2)}$ Jurusan Teknik Kimia Universitas Gadjah Mada, Yogyakarta 


\section{PENDAHULUAN}

Berkembangnya industri kimia di satu sisi bermanfaat bagi pertumbuhan ekonomi dan kesejahteraan rakyat, namun di sisi lain membawa dampak negatif yaitu menurunnya kualitas lingkungan akibat pembuangan limbah yang dihasilkannya. Salah satu industri kimia yang banyak menghasilkan limbah cair maupun padat yaitu industri penyamakan kulit.

Pengolahan air limbah industri penyamakan kulit meliputi pengolahan primer, pengolahan sekunder, dan pengolahan tersier. Kadar Chemical Oxygen Demand (COD) maksimum yang diperbolehkan dalam buangan air limbah industri penyamakan kulit sebesar (Keputusan Gubernur Kepala Daerah Istimewa Yogyakarta nomor 281/KPTS/1998 tentang Baku Mutu Limbah Cair Bagi Kegiatan Industri di Propinsi Daerah Istimewa Yogyakarta):

- $180 \mathrm{mg} / \mathrm{L}$ untuk proses penyamakan kulit menggunakan bahan penyamak nabati

- $90 \mathrm{mg} / \mathrm{L}$ untuk proses penyamakan kulit menggunakan krom dari kulit wet blue

- $100 \mathrm{mg} / \mathrm{L}$ untuk proses penyamakan kulit menggunakan krom dari kulit mentah garaman.

Polutan dalam air limbah industri penyamakan kulit yang memberikan kontribusi terhadap besarnya nilai COD diantaranya sisa protein dan lemak, surfaktan, anti bakteri, anti jamur, pewarna, dan bahan penyamak. Pengolahan tersier perlu dilakukan untuk menjamin buangan air limbah dapat memenuhi baku mutu di atas karena polutan berupa pewarna pada umumnya cukup stabil terhadap cahaya, panas, oksidator dan sulit didegradasi secara biologis (Mall dkk, 2006).

Teknologi pengolahan tersier untuk menghilangkan COD antara lain filtrasi membran, proses oksidasi, dan adsorpsi. Filtrasi membran dan proses oksidasi merupakan cara pengolahan yang mahal, rumit, memakan banyak waktu, dan membutuhkan tenaga terampil dalam pengoperasiannya (Amuda dan Ibrahim, 2006). Adsorpsi diketahui merupakan metode yang paling efisien untuk menghilangkan warna, bau, minyak, dan organik dari air limbah. Karbon aktif menjadi adsorben yang paling banyak dipakai karena kemampuan adsorpsinya yang sangat bagus, namun kelemahannya adalah harganya yang mahal sehingga tidak cocok untuk negara berkembang (Rachakornkij dkk, 2004). Hal ini mendorong banyak peneliti untuk mencari alternatif adsorben dengan harga yang lebih murah, diantaranya dengan memanfaatkan abu terbang bagas.

Abu terbang bagas adalah limbah industri gula yang didapat dari hasil pembakaran bagas di dalam boiler. Bahan ini tidak berharga bagi pabrik gula dan hanya perlu ongkos pengangkutan apabila ingin memanfaatkannya. Pembakaran bagas tebu menghasilkan dua macam abu yaitu abu dasar bagas (bagasse bottom ash) dan abu terbang bagas (bagasse fly ash). Warna abu dasar bagas lebih cerah dari pada abu terbang bagas karena mengandung karbon lebih sedikit. Lost on ignition pada abu terbang bagas mencapai $36,50 \%$ (Sudiyo dkk, 2006). Hal ini menunjukkan kadar bahan organik di dalamnya masih cukup tinggi sehingga menarik perhatian banyak peneliti yang mencoba menggunakan abu terbang bagas sebagai adsorben berbagai polutan dari limbah cair, Banyak peneliti telah menggunakan abu terbang bagas sebagai adsorben berbagai polutan dari limbah cair, diantaranya logam (Gupta dan Ali, 2004; Srivastava dkk, 2007; Taha, 2006), pewarna (Mall dkk, 2006; Mane dkk, 2007; Rachakornkij dkk, 2004), dan pestisida (Akhtar dkk, 2007; Gupta dan Ali, 2001).

Penelitian ini bertujuan untuk menguji peningkatan kemampuan abu terbang bagas yang diaktivasi secara kimia menggunakan $\mathrm{H}_{2} \mathrm{O}_{2}$ atau $\mathrm{H}_{2} \mathrm{SO}_{4}$ dalam mengurangi $\mathrm{COD}$ dalam air limbah industri penyamakan kulit dan mendapatkan model kesetimbangan adsorption isotherm yang sesuai pada pengurangan COD dalam air limbah industri penyamakan kulit menggunakan abu terbang bagas secara batch.

\section{BAHAN DAN METODE Bahan}

Bahan penelitian yaitu abu terbang bagas diperoleh dari dust collector PT. Madubaru Yogyakarta. Air limbah industri penyamakan kulit diperoleh dari Balai Besar Kulit, Karet, dan Plastik Yogyakarta. Kertas 
saring Whatmann 934-AH, $\mathrm{NaOH}, \mathrm{H}_{2} \mathrm{SO}_{4}$, dan $\mathrm{H}_{2} \mathrm{O}_{2}$ analytical grade (Merck).

\section{Alat}

Alat penelitian berupa neraca analitis (Mettler Toledo, AB204-S), oven (Memmert), pompa vakum (ABM, tipe 4EKF56CX-4), ayakan standard Tyler, alat uji COD closed refluks (Merck, Thermoreaktor TR 300), dan Fourier Transform Infrared Spectrofotometer (Shimadzu).

\section{Metode}

Penelitian dilakukan dengan tahapan sebagai berikut:

1. Persiapan air limbah industri penyamakan kulit

Air limbah dinetralkan dengan $\mathrm{NaOH}$ sampai $\mathrm{pH} 7$, didiamkan semalam lalu disaring dengan kertas saring Whatmann 934-AH.

2. Persiapan abu terbang bagas

Abu terbang bagas diayak dengan ukuran 20+35 mesh. Selanjutnya dilakukan aktivasi dengan beberapa metode, yaitu :

a. Tanpa bahan kimia

Abu terbang bagas dicuci dengan akuades, dipanaskan dalam oven pada suhu $100^{\circ} \mathrm{C}$ selama 24 jam lalu disimpan dalam desikator.

b. Aktivasi menggunakan $\mathrm{H}_{2} \mathrm{O}_{2}$

Sepuluh gram abu terbang bagas ditambah dengan $150 \mathrm{~mL} \mathrm{H}_{2} \mathrm{O}_{2}$ dengan konsentrasi tertentu (3 dan 7,5\%) lalu dipanaskan dalam oven selama 24 jam pada suhu $60^{\circ} \mathrm{C}$. Selanjutnya abu terbang bagas dicuci dengan akuades dan dioven kembali pada suhu $100^{\circ} \mathrm{C}$ selama 24 jam lalu disimpan dalam desikator.

c. Aktivasi menggunakan $\mathrm{H}_{2} \mathrm{SO}_{4}$

Sepuluh gram abu terbang bagas ditambah dengan $150 \mathrm{~mL} \mathrm{H}_{2} \mathrm{SO}_{4}$ dengan konsentrasi tertentu (3 dan 7,5\%) lalu dipanaskan dalam oven selama 24 jam pada suhu $60^{\circ} \mathrm{C}$. Selanjutnya abu terbang bagas dicuci dengan akuades dan dioven kembali pada suhu $100^{\circ} \mathrm{C}$ selama 24 jam lalu disimpan dalam desikator.

Abu terbang bagas yang diperoleh dari ketiga metode aktivasi di atas digunakan untuk proses adsorpsi secara batch. Air limbah dengan kadar COD 1189,44 mg/L sebanyak $50 \mathrm{~mL}$ dimasukkan ke dalam elenmeyer bersama-sama dengan $0,1 \mathrm{~g}$ abu terbang bagas. Campuran diaduk sampai semua abu tercelup ke dalam limbah lalu didiamkan semalam pada suhu kamar sampai tercapai kesetimbangan. Selanjutnya adsorben disaring dan dari air limbah diukur sisa CODnya. Metode aktivasi yang memberikan hasil adsorpsi paling baik digunakan pada tahapan penelitian selajutnya.

3. Percobaan adsorption isotherm

Air limbah dengan kadar COD tertentu sebanyak $50 \mathrm{~mL}$ dimasukkan ke dalam elenmeyer bersama-sama dengan abu terbang bagas dengan massa tertentu. Campuran diaduk sampai semua abu tercelup ke dalam limbah lalu didiamkan semalam pada suhu kamar sampai tercapai kesetimbangan. Selanjutnya adsorben disaring dan dari air limbah dihitung sisa CODnya.

4. Analisis hasil

Karakterisasi abu terbang bagas yang telah diaktivasi dilakukan dengan Fourier Transform Infrared Spectrophotometer Shimadzu untuk mengetahui gugus fungsional yang ada di permukaan adsorben dan dengan uji Bilangan Iodin sesuai ASTM D 4607-94, Standard Test Method for Determination of Iodine Number of Activated Carbon.

Kadar COD air limbah diukur sesuai metode SNI 6989.73:2009 Air dan air limbah Bagian 73: Cara uji Kebutuhan Oksigen Kimiawi (Chemical Oxygen Demand/COD) dengan refluks tertutup secara titrimetri.

Kandungan COD dalam abu terbang bagas yang berada pada kesetimbangan, $\mathrm{q}_{\mathrm{eq}}$ $(\mathrm{mg} / \mathrm{g})$, dihitung berdasarkan neraca massa, yaitu:

$\mathrm{q}_{\mathrm{eq}}=\frac{\left(\mathrm{C}_{0}-\mathrm{C}_{\mathrm{eq}}\right)}{\mathrm{W}} \mathrm{V}$

Keterangan:

$\mathrm{q}_{\mathrm{eq}}$ : Kandungan COD dalam abu terbang bagas yang berada pada kesetimbangan, $\mathrm{mg} / \mathrm{g}$ 
$\mathrm{C}_{\text {eq }}$ : Konsentasi COD limbah yang berada pada kesetimbangan, $\mathrm{mg} / \mathrm{L}$

$\mathrm{C}_{\mathrm{o}}$ : Konsentasi COD limbah sebelum adsorpsi, mg/L

$\mathrm{V}$ : Volume limbah, $\mathrm{mL}$

W : Massa abu terbang bagas, $g$

\section{HASIL DAN PEMBAHASAN}

\section{A. Percobaan aktivasi abu terbang bagas}

Menurut Gupta dan Sharma (2003), abu terbang bagas perlu diaktivasi dengan hidrogen peroksida agar kemampuan adsorpsinya lebih baik. Namun mereka tidak menampilkan perbandingan kemampuan adsorpsi abu terbang bagas antara sebelum dengan sesudah aktivasi. Untuk itu pada kemampuan abu terbang bagas dalam mengurangi COD air limbah industri penyamakan kulit. penelitian ini dilakukan percobaan aktivasi abu terbang bagas dengan 5 variasi metode aktivasi untuk melihat seberapa signifikan efek aktivasi dengan bahan kimia terhadap kemampuan abu terbang bagas dalam mengurangi COD air limbah industri penyamakan kulit.

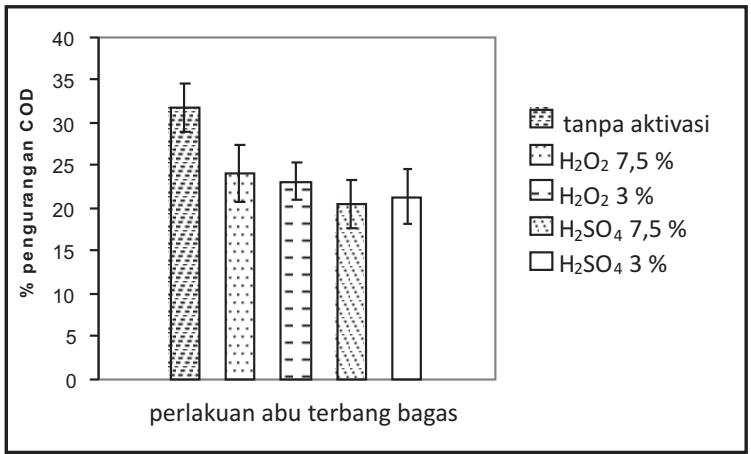

Gambar 1. Persentase pengurangan COD pada berbagai perlakuan aktivasi abu terbang bagas $\left(\mathrm{C}_{\mathrm{o}}=1189,4 \mathrm{mg} / \mathrm{L} ; \mathrm{pH}=7 ; \mathrm{V}=50 \mathrm{~mL} ; \mathrm{W}=0,1 \mathrm{~g}\right)$

Hasil uji pengurangan COD dengan abu terbang bagas secara batch pada berbagai variasi aktivasi terlihat pada Gambar 1. Tiap variasi dilakukan pengulangan sebanyak 5 kali. Hasil yang diperoleh ternyata berlawanan dengan apa yang ditemukan oleh (Gupta dan Sharma, 2003). Kemampuan abu terbang bagas dalam mengurangi COD dalam air limbah industri penyamakan kulit ternyata paling besar justru bila tidak diaktivasi dengan bahan kimia yaitu sebesar 31,7 \%. Perbedaan hasil yang diperoleh pada abu terbang bagas yang diaktivasi dengan asam sulfat dan hidrogen peroksida tampak tidak terlalu besar. Untuk mengetahui apakah variasi yang diperoleh berbeda nyata atau tidak maka dilakukan uji statistik One-Way Anova. Perhitungan uji statistik dilakukan dengan program SPSS 17.0. Hasil yang diperoleh seperti terlihat pada Tabel 1 menunjukkan bahwa pada tingkat kepercayaan $95 \%$, abu terbang bagas yang tidak diaktivasi dengan bahan kimia menghasilkan penurunan COD yang berbeda nyata dibandingkan variasi yang lain, sedangkan antara variasi aktivasi menggunakan $\mathrm{H}_{2} \mathrm{O}_{2} 7,5 \%, \mathrm{H}_{2} \mathrm{O}_{2} 3 \%$, $\mathrm{H}_{2} \mathrm{SO}_{4} 7,5 \%$, dan $\mathrm{H}_{2} \mathrm{SO}_{4} 3 \%$ menghasilkan penurunan $\mathrm{COD}$ yang tidak berbeda nyata.

Hasil uji abu terbang bagas menggunakan FTIR terlihat pada Gambar 2(a) sampai dengan Gambar 2(e). Gugus fungsional yang dapat diidentifikasi pada Gambar 2(a) antara lain terlihat pada bilangan gelombang berikut (Furniss, 1989):

$3425 \mathrm{~cm}^{-1}: \mathrm{O}^{-} \mathrm{H}$ stretching vibrations

$1627 \mathrm{~cm}^{-1}: \mathrm{C}=\mathrm{O}$ stretching vibrations

$1103 \mathrm{~cm}^{-1}: \mathrm{C}^{-} \mathrm{O}$ stretching vibrations

Gambar 2(b) sampai dengan 2(e) memperlihatkan bahwa baik jumlah maupun letak peak dengan intensitas yang cukup jelas relatif sama dengan Gambar 2(a). Hal ini menunjukkan bahwa pada percobaan proses aktivasi abu terbang bagas dengan asam sulfat dan hidrogen peroksida tidak timbul tipe gugus fungsional baru.

Bilangan iodin merupakan indikator porositas dalam karbon aktif yang dapat digunakan untuk memperkirakan luas permukaan untuk tipe karbon aktif tertentu. Namun hubungan bilangan iodin dengan luas permukaan tidak dapat digeneralisasi karena bervariasi tergantung dari bahan baku karbon aktif dan proses pembuatannya (ASTM,1999). Tabel 2 menunjukkan hasil uji bilangan iodin dari abu terbang bagas. Terlihat bahwa aktivasi abu terbang bagas dengan asam sulfat dan hidrogen peroksida mengakibatkan penurunan bilangan iodin. Hal ini kemungkinan diakibatkan oleh terjadinya proses degradasi struktur poros dari abu terbang bagas. 
Tabel 1. Hasil uji One-Way Anova persentase pengurangan COD pada berbagai variasi aktivasi abu terbang bagas

\begin{tabular}{|c|c|c|c|c|c|c|}
\hline \multirow[b]{2}{*}{ (I) variasi } & \multirow[b]{2}{*}{$(\mathrm{J})$ variasi } & \multirow{2}{*}{$\begin{array}{c}\text { Mean } \\
\text { Difference } \\
\text { (I-J) }\end{array}$} & \multirow[b]{2}{*}{ Std. Error } & \multirow[b]{2}{*}{ Sig. } & \multicolumn{2}{|c|}{$95 \%$ Confidence Interval } \\
\hline & & & & & $\begin{array}{l}\text { Lower } \\
\text { Bound }\end{array}$ & $\begin{array}{l}\text { Upper } \\
\text { Bound }\end{array}$ \\
\hline \multirow[t]{4}{*}{ tanpa aktivasi } & $\mathrm{H}_{2} \mathrm{O}_{2} 7,5 \%$ & $7,55526^{*}$ & 1,88760 & 0,007 & 1,6029 & 13,5076 \\
\hline & $\mathrm{H}_{2} \mathrm{O}_{2} 3 \%$ & $8,62126^{*}$ & 1,88760 & 0,002 & 2,6689 & 14,5736 \\
\hline & $\mathrm{H}_{2} \mathrm{SO}_{4} 7,5 \%$ & $11,23126^{*}$ & 1,88760 & 0,000 & 5,2789 & 17,1836 \\
\hline & $\mathrm{H}_{2} \mathrm{SO}_{4} 3 \%$ & $10,36126^{*}$ & 1,88760 & 0,000 & 4,4089 & 16,3136 \\
\hline \multirow[t]{4}{*}{$\mathrm{H}_{2} \mathrm{O}_{2} 7,5 \%$} & tanpa aktivasi & $-7,55526^{*}$ & 1,88760 & 0,007 & $-13,5076$ & $-1,6029$ \\
\hline & $\mathrm{H}_{2} \mathrm{O}_{2} 3 \%$ & 1,06600 & 1,88760 & 1,000 & $-4,8864$ & 7,0184 \\
\hline & $\mathrm{H}_{2} \mathrm{SO}_{4} 7,5 \%$ & 3,67600 & 1,88760 & 0,657 & $-2,2764$ & 9,6284 \\
\hline & $\mathrm{H}_{2} \mathrm{SO}_{4} 3 \%$ & 2,80600 & 1,88760 & 1,000 & $-3,1464$ & 8,7584 \\
\hline \multirow[t]{4}{*}{$\mathrm{H}_{2} \mathrm{O}_{2} 3 \%$} & tanpa aktivasi & $-8,62126^{*}$ & 1,88760 & 0,002 & $-14,5736$ & $-2,6689$ \\
\hline & $\mathrm{H}_{2} \mathrm{O}_{2} 7,5 \%$ & $-1,06600$ & 1,88760 & 1,000 & $-7,0184$ & 4,8864 \\
\hline & $\mathrm{H}_{2} \mathrm{SO}_{4} 7,5 \%$ & 2,61000 & 1,88760 & 1,000 & $-3,3424$ & 8,5624 \\
\hline & $\mathrm{H}_{2} \mathrm{SO}_{4} 3 \%$ & 1,74000 & 1,88760 & 1,000 & $-4,2124$ & 7,6924 \\
\hline \multirow[t]{4}{*}{$\mathrm{H}_{2} \mathrm{SO}_{4} 7,5 \%$} & tanpa aktivasi & $-11,23126^{*}$ & 1,88760 & 0,000 & $-17,1836$ & $-5,2789$ \\
\hline & $\mathrm{H}_{2} \mathrm{O}_{2} 7,5 \%$ & $-3,67600$ & 1,88760 & 0,657 & $-9,6284$ & 2,2764 \\
\hline & $\mathrm{H}_{2} \mathrm{O}_{2} 3 \%$ & $-2,61000$ & 1,88760 & 1,000 & $-8,5624$ & 3,3424 \\
\hline & $\mathrm{H}_{2} \mathrm{SO}_{4} 3 \%$ & $-0,87000$ & 1,88760 & 1,000 & $-6,8224$ & 5,0824 \\
\hline \multirow[t]{4}{*}{$\mathrm{H}_{2} \mathrm{SO}_{4} 3 \%$} & tanpa aktivasi & $-10,36126^{*}$ & 1,88760 & 0,000 & $-16,3136$ & $-4,4089$ \\
\hline & $\mathrm{H}_{2} \mathrm{O}_{2} 7,5 \%$ & $-2,80600$ & 1,88760 & 1,000 & $-8,7584$ & 3,1464 \\
\hline & $\mathrm{H}_{2} \mathrm{O}_{2} 3 \%$ & $-1,74000$ & 1,88760 & 1,000 & $-7,6924$ & 4,2124 \\
\hline & $\mathrm{H}_{2} \mathrm{SO}_{4} 7,5 \%$ & 0,87000 & 1,88760 & 1,000 & $-5,0824$ & 6,8224 \\
\hline
\end{tabular}

* Perbedaan rata-ratanya nyata atau signifikan.

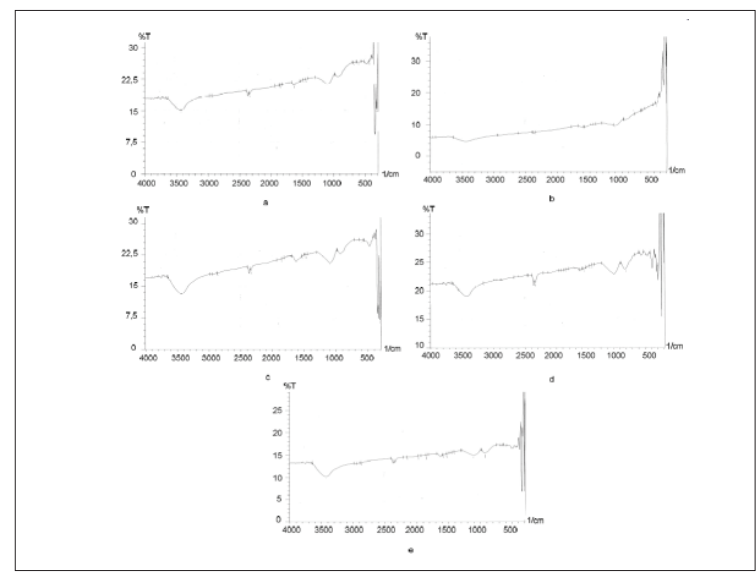

Gambar 2. Spektroskopi FTIR dari abu terbang bagas: (a) tanpa aktivasi dengan bahan kimia (b) diaktivasi dengan $\mathrm{H}_{2} \mathrm{O}_{2} 7,5 \%$

(c) diaktivasi dengan $\mathrm{H}_{2} \mathrm{O}_{2} 3,0 \%$ (d) diaktivasi dengan $\mathrm{H}_{2} \mathrm{SO}_{4} 7,5 \%$ (e) diaktivasi dengan $\mathrm{H}_{2} \mathrm{SO}_{4} 3,0 \%$
Tabel 2. Bilangan iodin pada berbagai variasi aktivasi abu terbang bagas

\begin{tabular}{lr} 
Perlakuan & Bilangan iodin, $\mathrm{mg} / \mathrm{g}$ \\
\hline Tanpa aktivasi & 310,382 \\
$\mathrm{H}_{2} \mathrm{O}_{2} 7,5 \%$ & 289,648 \\
$\mathrm{H}_{2} \mathrm{O}_{2} 3 \%$ & 295,177 \\
$\mathrm{H}_{2} \mathrm{SO}_{4} 7,5 \%$ & 244,724 \\
$\mathrm{H}_{2} \mathrm{SO}_{4} 3 \%$ & 241,269 \\
\hline
\end{tabular}

Penurunan luas permukaan adsorben setelah proses oksidasi juga ditemukan oleh (Choma dkk, 1999). Mereka melakukan proses oksidasi karbon aktif berbasis batubara (HZCH, WD, dan DTO) dari Gryf-Skand, Inc. (Polandia) dengan variasi oksidator berupa hidrogen peroksida $30 \%$, asam nitrat $65 \%$, dan asam perklorida 30\%. Menurut El-Hendawy 
(2003), penurunan luas permukaan karbon aktif setelah oksidasi disebabkan oleh dihasilkannya banyak macropore karena rusaknya micropore.

\section{B. Percobaan secara batch}

Korelasi kesetimbangan yang tepat diperlukan untuk mengoptimasi desain sistem adsorpsi. Tiga persamaan isotherm yaitu persamaan Freundlich, Langmuir, dan Temkin dipakai dalam penelitian ini untuk menggambarkan karakteristik kesetimbangan adsorpsi dari air limbah industri penyamakan kulit.

Konsentrasi COD air limbah sebelum proses adsorpsi, massa adsorben yang digunakan, konsentrasi COD setelah tercapai kesetimbangan, dan hasil perhitungan $\mathrm{q}_{\mathrm{eq}}$ ditunjukkan pada Tabel 3.

Tabel 3. Konsentrasi COD awal dan saat setimbang $(\mathrm{V}=50 \mathrm{~mL})$

\begin{tabular}{crrr}
$\begin{array}{c}\text { massa adsorben } \\
(\mathrm{W}), \mathrm{g}\end{array}$ & $\begin{array}{c}\mathrm{COD} \text { awal } \\
\left(\mathrm{C}_{\mathrm{o}}\right), \mathrm{mg} / \mathrm{L}\end{array}$ & $\begin{array}{r}\text { COD akhir } \\
\left(\mathrm{C}_{\mathrm{eq}}\right), \mathrm{mg} / \mathrm{L}\end{array}$ & $\begin{array}{r}\text { qeq } \\
\text { (persamaan } 1),\end{array}$ \\
\hline 0,05 & 1562,11 & 1451,52 & 110,59 \\
0,10 & 76,50 & 42,24 & 8,57 \\
0,10 & 153,00 & 77,44 & 18,89 \\
0,10 & 267,75 & 152,77 & 28,75 \\
0,10 & 1562,11 & 1313,28 & 124,42 \\
0,20 & 1665,79 & 1209,60 & 114,05 \\
0,40 & 52,53 & 24,19 & 3,54 \\
0,40 & 131,33 & 62,21 & 8,64 \\
0,40 & 262,66 & 131,33 & 16,42 \\
0,40 & 525,32 & 224,64 & 37,59 \\
0,40 & 787,98 & 390,53 & 49,68 \\
0,40 & 832,90 & 518,40 & 39,31 \\
0,40 & 1166,05 & 777,60 & 48,56 \\
0,40 & 1313,30 & 718,85 & 74,31 \\
\hline
\end{tabular}

Model Langmuir berasumsi permukaan adsorben seragam, semua molekul teradsorpsi tidak saling berinteraksi, semua molekul teradsorpsi melalui mekanisme yang sama, dan terbentuk monolayer saat adsorpsi maksimal (Do, 1998). Persamaan Langmuir dituliskan sebagai berikut (Aksu dan Gonen, 2004):

$\mathrm{q}_{\mathrm{eq}}=\frac{\mathrm{Q}^{\mathrm{o}} \mathrm{bC}_{\mathrm{eq}}}{1+\mathrm{bC}_{\mathrm{eq}}}$
Keterangan:

b: Konstanta terkait dengan afinitas binding sites, $\mathrm{L} / \mathrm{mg}$

$\mathrm{Q}^{\circ}$ : $\quad$ Kandungan $\mathrm{COD}$ dalam abu terbang bagas yang membentuk lapisan monolayer komplit, mg/g

Linierisasi persamaan (2) menghasilkan persamaan berikut:

$\frac{\mathrm{C}_{\mathrm{eq}}}{\mathrm{q}_{\mathrm{eq}}}=\frac{1}{\mathrm{Q}^{\circ} \mathrm{b}}+\frac{\mathrm{C}_{\mathrm{eq}}}{\mathrm{Q}^{\mathrm{o}}}$

Selanjutnya dibuat grafik hubungan antara $\mathrm{C}_{\mathrm{eq}}$ dengan $\mathrm{C}_{\mathrm{eq}} / \mathrm{q}_{\mathrm{eq}}$ menggunakan software Microsoft Excel. Parameterparameter dalam persamaan isoterm Langmuir yaitu $b$ dan $\mathrm{Q}^{\circ}$ diperoleh dengan membuat trendline bertipe regresi linier. Nilai $Q^{\circ}$ dan b yang diperoleh dari Persamaan (3) terlihat pada Tabel 4.

Persamaan Freundlich dirumuskan dengan mengambil asumsi permukaan adsorben heterogen dan distribusi panas adsorpsi di permukaan tidak seragam. Model Freundlich dituliskan sebagai berikut (Aksu dan Gonen, 2004):

$\mathrm{q}_{\mathrm{eq}}=\mathrm{K}_{\mathrm{F}} \mathrm{C}_{\mathrm{eq}}{ }^{1 / n}$

Keterangan:

$\mathrm{K}_{\mathrm{F}}$ : Konstanta persamaan Freundlich, $(\mathrm{mg} / \mathrm{g}) /(\mathrm{L} / \mathrm{mg})^{1 / \mathrm{n}}$

$1 / \mathrm{n}:$ Faktor heterogenitas

Persamaan (4) dapat dilinierisasi menjadi :

$\log \mathrm{q}_{\mathrm{eq}}=\log \mathrm{K}_{\mathrm{F}}+\frac{1}{\mathrm{n}} \log \mathrm{C}_{\mathrm{eq}}$

Selanjutnya dibuat grafik hubungan antara $\log \mathrm{C}_{\mathrm{eq}}$ dengan $\log \mathrm{q}_{\mathrm{eq}}$ menggunakan software Microsoft Excel. Parameterparameter dalam persamaan isoterm Freundlich yaitu $\mathrm{K}_{\mathrm{F}}$ dan $\mathrm{n}$ diperoleh dengan membuat trendline bertipe regresi linier. Nilai $K_{F}$ dan $n$ yang diperoleh dari Persamaan (5) terlihat pada Tabel 4

Persamaan Temkin berasumsi bahwa panas adsorpsi dari semua molekul dalam 
lapisan semakin berkurang bila permukaan adsorben semakin banyak yang tertutupi. Adsorpsi dicirikan dengan distribusi energi ikatan yang seragam (Mall dkk, 2005). Persamaan Temkin dituliskan sebagai berikut (Lataye dkk, 2006):

$\mathrm{q}_{\mathrm{eq}}=\mathrm{B}_{1} \ln \left(\mathrm{K}_{\mathrm{T}} \mathrm{C}_{\mathrm{eq}}\right)$

Keterangan:

$\mathrm{B}_{1}$ : Konstanta persamaan Temkin

$\mathrm{K}_{\mathrm{T}}$ : Konstanta ikatan pada kondisi

kesetimbangan terkait dengan energi ikatan maksimum (L/mg)

Persamaan (6) dapat dilinierisasi menjadi :

$\mathrm{q}_{\mathrm{eq}}=\mathrm{B}_{1} \ln \mathrm{K}_{\mathrm{T}}+\mathrm{B}_{1} \ln \mathrm{C}_{\mathrm{eq}}$

Selanjutnya dibuat grafik hubungan antara $\ln \mathrm{C}_{\mathrm{eq}}$ dengan $\mathrm{q}_{\mathrm{eq}}$ menggunakan software Microsoft Excel. Parameterparameter dalam persamaan isoterm Temkin yaitu $\mathrm{K}_{\mathrm{T}}$ dan $\mathrm{B}_{1}$ diperoleh dengan membuat trendline bertipe regresi linier. Nilai $\mathrm{K}_{\mathrm{T}}$ dan $\mathrm{B}_{1}$ yang diperoleh dari Persamaan (7) terlihat pada Tabel 4.

Tabel 4. Konstanta persamaan adsorption isotherm

\begin{tabular}{llc} 
Persamaan & Konstanta & $\begin{array}{c}\text { Koefisien } \\
\text { determinasi, } \mathrm{R}^{2}\end{array}$ \\
\hline Langmuir & $\mathrm{b}=7,9928.10^{4} \mathrm{~L} / \mathrm{mg}$ & 0,91 \\
& $\mathrm{Q}^{\mathrm{o}}=198,2161 \mathrm{mg} / \mathrm{g}$ & \\
Freundlich & $\begin{array}{l}\mathrm{K}_{\mathrm{F}}=0,4360(\mathrm{mg} / \mathrm{g}) /(\mathrm{L} / \mathrm{mg})^{1 / \mathrm{n}} \\
\mathrm{n}=1,2969\end{array}$ & 0,93 \\
Temkin & $\mathrm{B}_{1}=27,3300$ & \\
& $\mathrm{~K}_{\mathrm{T}}=0,02317 \mathrm{~L} / \mathrm{mg}$ & 0,81 \\
\hline
\end{tabular}

Terlihat dari Tabel 4 bahwa model yang paling cocok adalah Persamaan Freundlich karena dilihat dari koefisien determinasi yang didapatkan nilainya paling mendekati satu. Grafik hubungan $\mathrm{C}_{\mathrm{eq}}$ dan $\mathrm{q}_{\mathrm{eq}}$ dari data percobaan dan hasil pemodelan dengan Persamaan Freundlich, Langmuir, dan Temkin terlihat pada Gambar 3.
Model Langmuir berasumsi membentuk monolayer saat adsorpsi maksimal (Do, 1998). Persamaan Langmuir mengasumsikan bahwa pada $\mathrm{C}_{\mathrm{eq}}$ yang sangat besar nilai $\mathrm{q}_{\mathrm{eq}}$ akan mencapai batas maksimum yaitu sebesar $\mathrm{Q}^{\circ}$. Hasil hubungan $\mathrm{C}_{\text {eq }}$ dengan $\mathrm{q}_{\mathrm{eq}}$ yang diperoleh pada rentang percobaan yang dilakukan seperti terlihat pada Gambar 3 belum memperlihatkan secara tegas kecenderungan dalam membentuk asimptot.

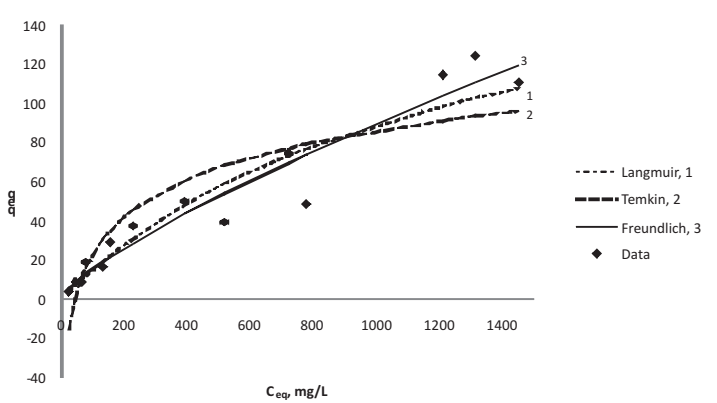

Gambar 3. Hubungan $\mathrm{C}_{\mathrm{eq}}$ dan $\mathrm{q}_{\mathrm{eq}}$ a dari data percobaan dan hasil pemodelan dengan Persamaan Freundlich, Langmuir, dan Temkin Model Temkin mempunyai kelemahan yaitu dibawah $\mathrm{C}_{\mathrm{eq}}$ sebesar $43,17 \mathrm{mg} / \mathrm{L}$, nilai $\mathrm{q}_{\mathrm{eq}}$ yang diperoleh bernilai negatif. Hal ini berarti model ini tidak bisa diaplikasikan dalam perhitungan adsorpsi dengan konsentrasi COD awal yang kecil.

\section{KESIMPULAN}

Kesimpulan yang dapat ditarik dari penelitian ini adalah sebagai berikut:

1. Abu terbang bagas memiliki kemampuan untuk mengurangi COD yang lebih baik bila tidak diaktivasi dengan asam sulfat maupun hidrogen peroksida $(3 \%$ dan $7,5 \%$ ). Aktivasi dengan bahan kimia tersebut tidak menambah tipe gugus fungsional di permukaan adsorben. Penurunan bilangan iodin pada abu terbang bagas yang diaktivasi menunjukkan bahwa kemungkinan terjadi kerusakan struktur porous.

2. Persamaan Freundlich paling cocok untuk memodelkan kesetimbangan adsorption isotherm pengurangan COD dengan abu 
terbang bagas secara batch. Nilai $\mathrm{K}_{\mathrm{F}}$ dan $\mathrm{n}$ yang diperoleh berturut-turut sebesar 0,4360 $(\mathrm{mg} / \mathrm{g}) /(\mathrm{L} / \mathrm{mg})^{1 / \mathrm{n}}$ dan 1,2969 dengan nilai koefisien korelasi yang didapatkan yaitu 0,93.

\section{DAFTAR PUSTAKA}

Akhtar, M., Hasany, S.M., Bhanger, M.I., dan Iqbal, S., 2007. Low Cost Sorbents for The Removal of Methyl Parathion Pesticide from Aqueous Solutions, Chemosphere, 66, 1829-1838.

Aksu, Z. dan Gonen, F., 2004. Biosorption of Phenol by Immobilized Activated Sludge in a Continuous Packed Bed: Prediction of Breakthrough Curve, Process Biochemistry, 39, 599-613.

Amuda, O.S. dan Ibrahim A.O., 2006. Industrial Wastewater Treatment Using Natural Material as Adsorbent, African J. Biotechnol., 5, 1483-1487.

ASTM, 1999. Standard Test Method for Determination of Iodine Number of Activated Carbon.

Choma, J., Burakiewicz-Mortka, W., Jaroniec, M., Li, Z., Klinik, J., 1999. Monitoring Changes in Surface dan Structural Properties of Porous Carbons Modified by Different Oxidizing Agents, J. Colloid Interface Sci., 214, 438-446.

Do, D.D., 1998. Adsorption Analysis: Equilibria and Kinetics, Series on Chemical Engineering, Vol 2, pp. 13-16, Imperial College Press.

El-Hendawy, A.N., 2003. Influence of $\mathrm{HNO}_{3}$ Oxidation on The Structure and Adsorptive Properties of Corncobbased Activated Carbon, Carbon, 41, 713-722.

Furniss, B.S., Hannaford, A.J., Smith, P.W., dan Tatchell, A.R., 1989. Vogel's Textbook of Practical Organic Chemistry, $5^{\text {th }}$ ed., pp. 1413-1422, Longman Scientific and Technical.
Gupta, V.K. dan Ali, I., 2001. Removal of DDD and DDE from Wastewater Using Bagasse Fly Ash, A Sugar Industry Waste, Wat. Res., 35, 33-40. oid Interface Sci., 271, 321-328.

Gupta, V.K. dan Ali, I., 2004. Removal of Lead and Chromium from Wastewater Using Bagasse Fly Ash- a Sugar Industry Waste, J. Coll

Gupta, V.K. dan Sharma, S., 2003. Removal of Zink from Aqueous Solution Using Bagasse Fly Ash-Low Cost Adsorbent, Ind. Eng. Chem. Res., 42, 6619-6624.

Keputusan Gubernur Kepala Daerah Istimewa Yogyakarta nomor 281/KPTS/1998 tentang Baku Mutu Limbah Cair Bagi Kegiatan Industri di Propinsi Daerah Istimewa Yogyakarta

Lataye, D.H., Mishra, I.M., dan Mall, I.D., 2006. Removal of Pyridine from Aqueous Solution By Adsorption on Bagasse Fly Ash, Ind. Eng. Chem. Res., 45, 3934-3943.

Mall, I.D., Srivastava, V.C. Agarwal, N.K., dan Mishra, I.M., 2005. Adsorptive Removal of Malachite Green Dye from Aqueous Solution by Bagasse Fly Ash and Activated Carbon-Kinetic Study dan Equilibrium Isoterm Analysis, Colloids Surface, 264, 17-28.

Mall, I.D., Srivastava, V.C., dan Agarwal, N.K., 2006. Adsorptive Removal of Auramine-O: Kinetic and Equilibrium Study, J. Hazard. Mater., Doi:10.1016/jhazmat.2006.09.059.

Mane, V.S., Mall, I.D., dan Srivastava, V.C., 2007. Use of Bagasse Fly Ash As An Adsorbent for The Removal of Brilliant Green Dye from Aqueous Solution, Dyes Pigments, 73, 269-278.

Rachakornkij, M., Ruangchuay, S., dan Teachakulwiroj, S., 2004. Removal of Reaktif Dyes from Aqueous Solution Using Bagasse Fly Ash, Songklanakarin J. Sci. Technol., 26, 1324. 
SNI 6989.73:2009. Air dan air limbah Bagian 73: Cara uji Kebutuhan Oksigen Kimiawi (Chemical Oxygen Demand/COD) dengan refluks tertutup secara titrimetri.

Srivastava, V.C., Mall, I.D., dan Mishra, I.M., 2007. Multicomponent Adsorption Study of Metal Ions onto Bagasse Fly Ash using Taguchi's Design of Experimental Methodology, Ind. Eng. Chem. Res., 46, 5697-5706.
Sudiyo, R., Sumardi, P.C., dan Prasetya, A., 2006. Recovery of Silica from Bagasse Ashes of Sugar-cane Industry in Yogyakarta, Proceeding Final Report Hi Link Project Research 2006.

Taha, G.M., 2006. Utilization of Low Cost Waste material Bagasse Fly Ash in Removing of $\mathrm{Cu}^{2+}, \mathrm{Ni}^{2+}, \mathrm{Zn}^{2+}$, and $\mathrm{Cr}^{3+}$ from Industrial Wastewater, Ground Water Monitoring dan Remediation, 26, 137-141. 